\title{
Trophic spectrum of the juvenile roosterfish, Nematistius pectoralis Gill, 1862 (Perciformes: Nematistiidae), in Almejas Bay, Baja California Sur, Mexico
}

\author{
Espectro trófico de los juveniles del pejegallo, Nematistius pectoralis Gill, 1862 \\ (Perciformes: Nematistiidae), en Bahía Almejas, Baja California Sur, México \\ Jesús Rodríguez-Romero', Xchel G. Moreno-Sánchez², Leonardo A. \\ Abitia-Cárdenas ${ }^{2}$ and Deivis S. Palacios-Salgado ${ }^{2}$ \\ ${ }^{1}$ Centro de Investigaciones Biológicas del Noroeste (CIBNOR), Apdo. Postal 128, La Paz, B.C.S.,C.P. 23000, México \\ ${ }^{2}$ Centro Interdisciplinario de Ciencias Marinas (CICIMAR-IPN), Departamento de Pesquerías y \\ Biología Marina. Apdo. Postal 592. La Paz, Baja California Sur, México. C.P. 23000 \\ xchel.moreno@gmail.com
}

\begin{abstract}
Resumen.- Este trabajo es la primera contribución al conocimiento de la dieta del Pejegallo Nematistius pectoralis, capturado en Bahía Almejas, Baja California Sur, México. Se describe cualitativa y cuantitativamente el espectro trófico de 59 ejemplares de $N$. pectoralis, usando los métodos tradicionales de frecuencia de aparición, numérico y peso, así como el índice de importancia relativa. En Total se identificaron 10 especies-
\end{abstract}

\section{Introduction}

Within the fish components of the coastal ecosystems, pelagic fishes have a great importance due to their ecology, as energy exporting and importing organisms within the far-reaching coastal zones. They also provide an economically viable product as indicated by their capture volume, as well as by generating both direct and indirect employment in the sport fishing industry (Ditton et al. 1996).

One of the numerous coastal pelagic species in the Pacific Ocean is the roosterfish, Nematistius pectoralis Gill, 1862, which can be identified by seven characteristic spines in its dorsal fin, the first two of which are small, while the remaining five are very long and filamentous. $N$. pectoralis can be found along the Pacific Ocean from San Clemente in southern California, to San Lorenzo Island in Peru, including the Gulf of California and the Galapagos Islands (Love et al. 2005). It grows to a length of $191 \mathrm{~cm}$; its vertical range is 0 to $20 \mathrm{~m}$ (Robertson \& Allen 2002).

In spite of the ecological and economic relevance of the roosterfish $N$. pectoralis, only a very few scientific studies on its biology have been made, both at a national and international levels (Hobson 1968). Thus, the present study becomes important since it characterizes the food habits of the roosterfish $N$. pectoralis, in order to presa de las cuales 9 fueron peces y un cefalópodo. Se determino que el pejegallo, es un depredador ictiófago activo el cual incide principalmente sobre especies de peces que forman cardúmenes como los son Eucinostomus dowii, E. gacilis, Anchoa ischana y Anchoa spp.

Palabras clave: Predadores piscivoros, especies pelágicocostera, cardúmenes de peces

determine its place and functional role in the trophic chain of the coastal ecosystem.

\section{Material and methods}

The fish were caught bimonthly from March of 1998 to February of 1999 , in Almejas Bay $\left(24^{\circ} 20^{\prime}\right.$ and $24^{\circ} 35^{\prime} \mathrm{N}$ and $111^{\circ} 18^{\prime}$ and $111^{\circ} 50^{\prime} \mathrm{W}$ ) which is within the lagoon complex of Magdalena Bay, in the western coast of southern Baja California, Mexico (Wiggins 1980).

The specimens studied to come from catch made by the artisanal fishermen in the area. For captures gill nets (80 $\mathrm{m}$ long and $3 \mathrm{~m}$ wide and $9 \mathrm{~cm}$ mesh size) were utilized. The net were set at sunset (18:00) and recovered at sunrise (06:00), at 6 different locations in Almejas Bay at depths of 2 to $5 \mathrm{~m}$. The roosterfish individuals obtained had total lengths ranging 250 a $320 \mathrm{~mm}$.

Stomach contents were collected and fixed in $10 \%$ formaldehyde, afterwards it were stored in plastic bags previously labeled and carried to the Centro de Investigaciones Biológicas del Noroeste (CIBNOR) in La Paz, Mexico, for processing and analysis.

Stomach content analyses were made separating the prey-items according to their taxonomic group, at their lowest possible taxonomic level. Based on their digestion state, contents were counted and weighed to the nearest $0.1 \mathrm{mg}$ (Arizmendi-Rodriguez et al. 2006, Moreno- 
Sánchez et al. 2009). The taxonomic identification of the prey was made by means of external characters when the degree of digestion was not very advanced, using the keys of Miller \& Lea (1972), Fischer et al. (1995) Thomson et al. (2000). To identify other fish remains and vertebral characteristics, the works of Clothier (1950), Monod (1968), and Miller \& Jorgensen (1973) were used. Cephalopods were identified with the key of Wolff (1984).

The preys were recorded quantitatively, by number $(\mathrm{N})$, weight $(\mathrm{W})$ in grams, and frequency of occurrence (\%FO) (Hyslop 1980). The Index of Relative Importance (IRI) of Pinkas et al. (1971) was also used to corroborate the importance of each prey-item.

The diet breadth (Bi) was calculated using the standardized index of Levin (Hurlbert 1978) from the absolute values determined by the numerical method. This index produces values from 0 to 1 . Low values $(<0.6)$ indicate a specialist predator that use few prey resources and prefers certain prey (specialist predator) and high values $(>0.6)$ indicate a generalist predator that use all resources without preferences (Krebs 1989, Labropoulou \& Eleftheriou 1997).

\section{Results}

In the sampling area Nematistius pectoralis was recorded in May, July, September and November 1998, with 83 specimens captured. Fifty nine $(71 \%)$ of them had stomach contents, whereas the remaining 24 (29\%) had their stomachs empty.

Ten prey-items were identified in the roosterfish diet: nine of them were fish (Pseudupeneus grandisquamis, Anchoa ischana, Eucinostomus dowii, E. gracilis, Mugil curema, Anchoa spp. Anchovia macrolepidota, Selar crumenophthalmus and Haemulon scudderi) and the remainder was a cephalopod Loligo spp. (Table 1).

\section{Table 1}

Absolute values and percentages of the trophic spectrum composition of roosterfish Nematistius pectoralis in Almejas Bay, BCS, Mexico, as determined by number $(\mathrm{N})$, weight $(\mathrm{W})$, frequency of occurrence (FO), and index of relative importance (IRI)

Composición del espectro trófico del pejegallo Nematistius pectoralis en Bahía Almejas, BCS, representado por los valores absolutos y porcentuales de los métodos numérico $(\mathrm{N})$, gravimétrico (W), frecuencia de aparición (FO), e índice de importancia relativa (IRI)

\begin{tabular}{|c|c|c|c|c|c|c|c|c|}
\hline Prey items & FO & $\%$ FO & $\mathrm{N}$ & $\% \mathrm{~N}$ & W & $\% \mathrm{~W}$ & IRI & $\%$ IRI \\
\hline \multicolumn{9}{|l|}{ Mollusca } \\
\hline \multicolumn{9}{|l|}{ Cephalopoda } \\
\hline \multicolumn{9}{|l|}{ Teuthoidea } \\
\hline \multicolumn{9}{|l|}{ Loliginidae } \\
\hline Loligo spp. & 3.0 & 5.0 & 3.0 & 3.2 & 17.0 & 1.8 & 25.9 & 0.6 \\
\hline \multicolumn{9}{|l|}{ Vertebrata } \\
\hline \multicolumn{9}{|l|}{ Osteichthyes } \\
\hline \multicolumn{9}{|l|}{ Clupeiformes } \\
\hline \multicolumn{9}{|l|}{ Engraulidae } \\
\hline Anchoa ischana & 16.0 & 27.1 & 18.0 & 19.5 & 139.0 & 14.9 & 936.7 & 24.1 \\
\hline Anchoa spp. & 16.0 & 27.1 & 20.0 & 21.7 & 69.0 & 7.4 & 791.1 & 20.3 \\
\hline Anchovia macrolepidota & 5.0 & 8.4 & 5.0 & 5.4 & 129.0 & 13.9 & 163.8 & 4.2 \\
\hline \multicolumn{9}{|l|}{ Perciformes } \\
\hline \multicolumn{9}{|l|}{ Mullidae } \\
\hline Pseudupeneus grandisquamis & 2.0 & 3.3 & 2.0 & 2.1 & 45.0 & 4.8 & 23.8 & 0.6 \\
\hline \multicolumn{9}{|l|}{ Gerridae } \\
\hline Eucinostomus dowii & 13.0 & 22.0 & 15.0 & 16.3 & 156.0 & 16.8 & 729.6 & 18.7 \\
\hline Eucinostomus gracilis & 15.0 & 25.4 & 18.0 & 19.5 & 170.0 & 18.3 & 963.1 & 24.8 \\
\hline \multicolumn{9}{|l|}{ Mugilidae } \\
\hline Mugil curema & 1.0 & 1.6 & 1.0 & 1.0 & 16.0 & 1.7 & 4.7 & 0.1 \\
\hline \multicolumn{9}{|l|}{ Carangidae } \\
\hline Selar crumenophthalmus & 3.0 & 5.0 & 3.0 & 3.2 & 100.0 & 10.7 & 71.3 & 1.8 \\
\hline \multicolumn{9}{|l|}{ Haemulidae } \\
\hline Haemulon scudderi & 6.0 & 10.1 & 7.0 & 7.6 & 87.0 & 9.3 & 172.7 & 4.4 \\
\hline Total & 59 & & 92 & 100 & 928 & 100 & 3883.17 & 100 \\
\hline
\end{tabular}


According to the numerical method, a total of 92 organisms were quantified, and the dominant fish species was Anchoa spp. representing the 21,73\% (20 organisms), followed by Anchoa ischana, and Eucinostomus gracilis with $19.56 \%$ (18 for each species), as well as E. dowii with the $16.30 \%$ (15) (Table 1).

The total accumulated weight of prey in the 83 stomachs was $928 \mathrm{~g}$. The most important items by percentage weight were Eucinostomus gracilis with $18.31 \%$ (170 g), E. dowii with 16.81\% (156 g), Anchoa ischana, with $14.97 \%(139 \mathrm{~g})$ and Selar crumenophthalmus with the $10.77 \%$ (100 g) (Table 1). The Index of Relative Importance (IRI) showed that the most important items were Eucinostomus gracilis (24.80\%), Anchoa ischana (24.12\%), Anchoa spp. (20.37\%) and E. dowii (18.78\%) (Table 1, Fig. 1).

When calculating Levin's standardized index, $(\mathrm{BI}=$ 0.57 ), it was found that the breadth of the diet is relatively narrow, indicating that the roosterfish $N$. pectoralis should be considered as a specialist predator.

\section{Discussion}

The Laguna Complex of Magdalena-Almejas Bay is known as a zone of high productivity throughout the entire year (Bakun 1973). This area is used by many marine species including coastal pelagic fish for raising and feeding. The roosterfish $N$. pectoralis is considered to be a nonpermanent resident fish as indicated by the noticeable seasonality of its captures (Moreno-Sánchez 2004). During the study period of main abundances of $N$. pectoralis were observed during July and September, indicating that their presence is likely due to behavioral nutritional patterns and/or for reproduction.

The diet documented may differ for adults organisms collected offshore, as our data are based on juveniles that occupy inshore estuaries and lagoons.

The trophic spectrum of roosterfish consisted of 10 items (nine fish and a cephalopod), mainly members of the pelagic fish communities of the coastal zone. They are very mobile organisms in the water column, therefore

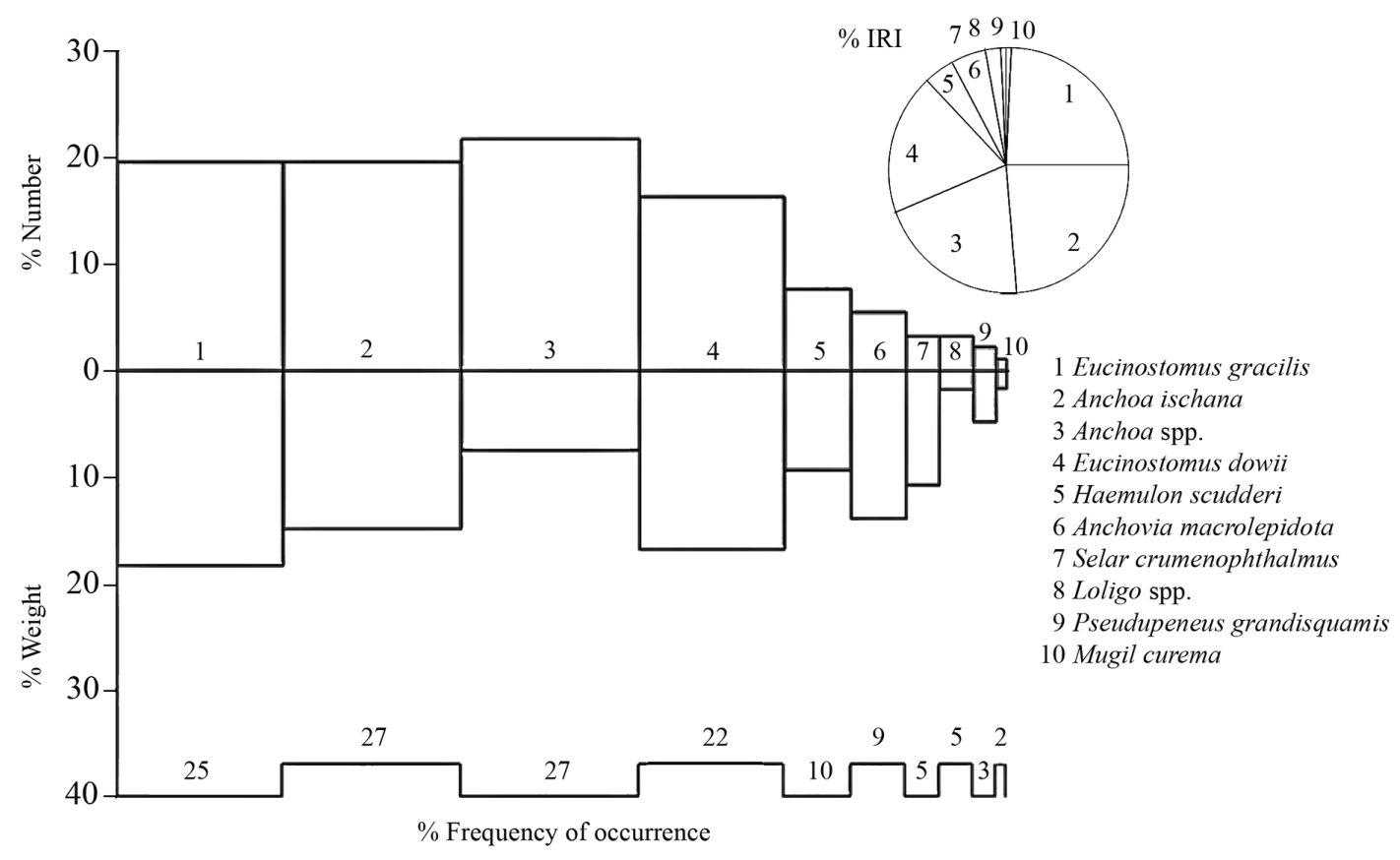

Figure 1

Trophic spectrum of roosterfish $N$. pectoralis shown as percentage by number, weight, frequency of occurrence, and index of relative importance (\% IRI)

Espectro trófico del pejegallo $N$. pectoralis representado por porcentaje de número, peso, frecuencia de aparición, e índice de importancia relativa (\% IRI) 
it can be concluded that the roosterfish is an active carnivorous predator. This conclusion is reinforced by morphological characteristics of this predator, like dentition composed of small and razor-sharp teeth on both jaws, on the vomer and palate, a typical predatory characteristic, and also by the body is long and deeper with a dorsally convex profile. Also the pectoral fins are long and confer the fish a great mobility within the entire water column (Fischer et al. 1995).

The diet analyses indicate that the roosterfish is a specialist predator even though its trophic spectrum was composed of 10 preys with four of them contributing to $88 \%$ of its diet. Two species belong to the family Gerridae (Eucinostomus dowii and E. gracilis both demersal) and two to the family Engraulidae (Anchoa ischana and Anchoa spp.). These last species are known to form aggregations in the pelagic coastal zone and are very abundant in the lagoon complex of Magdalena-Almejas Bay.

After 600 hours of observation in several areas in the Gulf of California, Hobson (1968) described the predatory behavior of the roosterfish, determining that it is an active crepuscular predator that feeds on schooling prey at depths between the 3 and 4 meters, which is in agreement with the results of this study.

In summary our work confirms the previously been reported by Hobson (1968); the roosterfish of the Gulf of California is a specialist predator feeding mainly on pelagic fish that form schools such as Anchoa ischana, Eucinostomus gracilis and Anchoa spp.

\section{Acknowledgments}

We are grateful to Centro Investigaciones Biológicas del Noroeste (CIB) for their financial support. Similarly to wish to thank the Instituto Politécnico Nacional (IPN) for support received through COFAA and EDI. XG Moreno and DS Palacios also thank the Consejo Nacional de Ciencia y Tecnología (CONACyT) and Programa Institucional de Formación de Investigadores (PIFI-IPN). Finally, we thank two anonymous referees for their comments and suggestions.

\section{Literature cited}

Arizmendi-Rodriguez DI, LA Abitia-Cardenas, F GalvanMagaña \& I Trejo-Escamilla. 2006. Food habits of sailfish Istiophorus platypterus off Mazatlan, Sinaloa, Mexico. Bulletin of Marine Science 79(3): 777-791.

Bakun A. 1973. Coastal upwelling indices, West coast of North America, 1976-71. NOAA Technical Report NMFS SSRF671: 1-103.
Clothier CR. 1950. A key to some southern California fishes based on vertebral characters. California Department of Fish and Game, Fish Bulletin 79: 1-83.

Ditton RB, SR Grimes \& LD Finkelstein. 1996. A social and economic study of the recreational billfish fishery in the southern Baja Area of Mexico, 50 pp. Texas A\&M University/ The Billfish Research and Conservation Foundation, Fort Lauderdale.

Fischer W, F Krupp, W Schneider, C Sommer, KE Carpenter \& V Niem. 1995. Guía FAO para la identificación de peces para los fines de pesca. Pacífico Centro-Oriental. Vol. II y III. Vertebrados, Parte 1/2: 647-1813. FAO, Roma.

Hobson ES. 1968. Predatory behavior of some shore fishes in the Gulf of California. United States Fish and Wildlife Service Research Reports 72: 1-92.

Hurlbert SH. 1978. The measurement of niche overlap and some relatives. Ecology 59: 67-77.

Hyslop EJ. 1980. Stomach contents analysis- a review of methods and their application. Journal of Fish Biology 17: 411-429.

Krebs CJ. 1989. Ecological methodology, 473 pp. Harper and Row, New York.

Labropoulou M \& A Eleftheriou. 1997. The foraging ecology of two pairs of congeneric demersal fish species: importance of morphological characteristics in prey selection. Journal of Fish Biology 50: 324-340.

Love MS, CW Mecklenburg, TA Mecklenburg \& LK Thorsteinson. 2005. Resource inventory of marine and estuarine fishes of the West Coast and Alaska: A Checklist of North Pacific and Arctic Ocean species from Baja California to the Alaska-Yukon Border, 276 pp. U.S. Department of the Interior, U.S. Geological Survey, Biological Resources Division, Seattle, Washington.

Miller DJ \& SC Jorgensen. 1973. Meristic characters of some marine fishes of the western Atlantic Ocean. California. Department of Fish and Game, Fish Bulletin 71: 301-312.

Miller DJ \& RN Lea. 1972. Guide to the coastal marine fishes of California. California Department of Fish and Game, Fish Bulletin 157: 1-249.

Monod T. 1968. Le complexe urophore des poissons téléostéens. Memoires de l'Institut Fondamental d'Afrique Noire 81: 1-705.

Moreno-Sánchez XG. 2004. Estructura comunitaria e interrelaciones tróficas de los peces de bahía Almejas, Baja California Sur, México. Tesis de Maestría, IPN-CICIMAR, La Paz, 97 pp.

Moreno-Sánchez XG, LA Abitia-Cárdenas, A FavilaBautista, FJ Gutiérrez-Sánchez \& DS Palacios-Salgado. 2009. Ecología trófica del pez Arothron meleagris (Tetraodontiformes: Tetraodontidae) en el arrecifes de Los Frailes, Baja California Sur, México. Revista de Biología Tropical 57(1-2): 113-123. 
Pinkas L, MS Oliphant \& ILK Iverson. 1971. Food habits of albacore, bluefin tuna and bonito in California waters. California Department of Fish and Game, Fish Bulletin 152: 1-105.

Robertson R \& G Allen. 2002. Shorefishes of the Tropical Eastern Pacific: an Information System. CD-ROM. Smithsonian Tropical Research Institute, Balboa, Panama.
Thomson AD, DT Findley \& N Kerstitch. 1979. Reef Fishes of the Sea of Cortez, 302 pp. John Wiley \& Sons, New York.

Wiggins IL. 1980. Flora of Baja California, 1025 pp. Stanford University Press, Stanford.

Wolff CA. 1984. Identification and estimation of size from the beaks of eighteen species of cephalopods from the Pacific Ocean. NOAA Technical Report, NMFS 17: 1-50.

Recibido el 12 de febrero de 2009 y aceptado el 28 de septiembre de 2009 